\title{
En solitär på barrikaden
}

\author{
Recension av Jan Å. Johansson (red.), Sören Wibe. \\ Fritänkare och vägbrytare (Celanders förlag, Lund 2016)
}

\section{ANDERS BJÖRNSSON}

Sören Wibe (1946-2010) uppnådde inte pensionsåldern, men tvivelsutan uppnådde han mycket annat. Boken som utkom till sjuttioårsdagen av hans födelse bär syn för sägen. I kortare betraktelser om personen privatmannen, politikern, forskaren - och de miljöer där han har varit verksam framtonar bilden av en kraftkarl som på många sätt påverkade villkoren för det intellektuella och offentliga meningsutbytet $i$ vårt land. Wibe var en polemiker av rang, han uppträdde chosefritt samt hade ett frustande intresse för väsentliga samtidsfrågor.

Många kanske minns honom som en glödande motståndare mot svenskt EU-medlemskap; i folkomröstningen om euron 2003 var han instrumentell för nej-resultatet, tillsammans med ett antal andra nationalekonomer, varav en (Karl-Gustaf Löfgren) medverkar i denna bok. För andra har han varit läraren, handledaren, inspiratören, som gjorde skogsekonomi till en respektabel vetenskaplig disciplin. Flera ytterligare strängar på sin lyra hade han synbarligen: tyckte om att fiska, sjunga Evert Taube, spela bridge, följa lördagsfotbollen på tv, samla pengar till motståndet mot Sovjetunionens krig i Afghanistan och delta i solidaritetsarbetet med Palestina.

Norrlandspojke. Född i Östersund. En ingalunda spikrak akademisk karriär, med naturvetenskap i grundexamen. Vänsterengagemang, vilket ledde till en kortare kommunalpolitisk sejour för VPK i den unga universitetsstaden Umeå. Övergång till socialdemokratin och en av Sveriges 
första europaparlamentariker, därefter riksdagsman; i bägge fallen fick en mandatperiod räcka, trots rekordmånga personkryss på valsedlarna. Till slut ordförande i Junilistan som med något tiotusental röster gick miste om fortsatt parlamentarisk representation i Bryssel i EU-valet 2009. Under hela denna tid aktiv som skribent och agitator, som engagerande universitetslärare och författare av vetenskapliga skrifter.

De som har bidragit till boken om Sören Wibe - tunn till formatet men rik till stoffet - ser honom som en solitär närmast, men med förmåga dra stora skaror med sig. På bilderna av honom ser han trygg och stabil ut, leende humoristisk, gestikulerande. Till staturen har han likheter med den en halv generation äldre forskarkollegan Bo Gustafsson, ekonomhistoriker i Uppsala, KFML:s förste ordförande, som skymtar förbi i ett av bokens bidrag där bilden tecknas av smågruppsvänsterns gyllene decennium, 1965-1975, då de båda positionerade sig på ytterkantskartan. Också Gustafsson blev partibytare men, till sin besvikelse, utan att tilldelas någon roll av det stora arbetarpartiet. Flera av Wibes insatser däremot blev politiskt verkningsfulla. Tillsammans med nationalekonomen Lars Hultkrantz, före detta clartéist som även han bytte fot men blev folkpartist, medverkade han till en liberalisering av landets skogslagstiftning, och han ställde sig i tidningsartiklar ytterst skeptisk till larmrapporter om försämrad artrikedom som följd av det moderna skogsbruket.

Wibes roll som "fritänkare", för att knyta an till bokens undertitel, sticker av mot den svenska rörelsetraditionen. Inom fack och parti har de rörelseintellektuella oftast sugits upp av apparaterna, blivit lojala reformbyråkrater eller organisationsfunktionärer. Wibe behöll sitt oberoende genom en stadigvarande bas i akademin; samtidigt vände han aldrig ryggen åt sin familjebakgrund i arbetarklassen, med en fader som var förrådsman och gårdskarl och en moder som dubbelarbetade. I det Wibeska hemmet dracks inte standardmjölk utan skummjölk, några ören billigare. När Sören höll på att bli sämst i klassen i tyska, fick han en uppsträckning av modern som lärde honom att inse att det var hennes slit som möjliggjorde hans studier. Uppriktighet av detta något kärva slag tycks ha blivit ett signum också för honom själv, inte minst i relationen till vissa uppburna ekonomer. 
Exemplet Sören Wibe visar väl att det sällan går att dra en skarp skiljelinje mellan arbetare och akademiker. I det borgerliga Sverige har det aldrig funnits något tydligt skikt av bildningsborgerskap, och i socialdemokratins Sverige stod alltid bildning och självbildning högt i kurs. Kunskapssamhället var på plats långt innan det kom i var mans mun - i samma ögonblick som de svenska elevernas resultat, på skol- och högskolenivå, paradoxalt nog började sjunka drastiskt! Numera är inte längre tillgängligheten på kunskap en bristfaktor i samhället, däremot fliten, den andliga odlingen, den individuella ansträngningen som i Wibes eget fall verkar ha fungerat som en outtömlig källa till energi och återkoppling. Han var, skriver Wibes före detta doktorand Bengt Kriström, ”en akademiker av den gamla skolan, en bärare av ett utbildningsideal som i dag förefaller tillhöra det förflutna”. Det idealet - saklighet, respekt för detaljer, disciplinerade studier, förakt för svammel och allmän lathet, kombinationen av teori och empiri - fanns också väl företrätt inom arbetarrörelsen.

Jag anser vidare att exemplet Wibe visar någonting annat: att det går att åstadkomma åtskilligt också från en minoritetsposition. Man behöver inte lägga sig i mitten och synas allmänt välartad. Wibe var folktalare och tillgrep gärna den direkta appellen; ändå skulle ingen komma på tanken att kalla honom populist eller extremist. Han fortsatte, som det verkar, att vara en EU-skeptiker, även om han accepterade det svenska unionsmedlemskapet som ett faktum. Han ansåg att välfärdsstaten skulle komma att avlövas genom teknokratiska lösningar på övernationell nivå, och han fann det bisarrt att ett visst ekonomiskt system - marknadsekonomin - skrevs in i EU:s konstitutioner, när sådana formuleringar saknas i de nationella författningarna som har framgått ur demokratiska val. EMU-systemet var en expertmodell som Wibe med stor framgång bekämpade för svenskt vidkommande och som sedan har visat sig så fantastiskt förödande för de länder som anslöt sig till den gemensamma valutan.

Även om Wibe i denna volym inte avporträtteras i frack, så blev han ändå ledamot av kunglig akademi (KSLA), och den tidskrift som han grundade 1995, Journal of Forest Economics, är i dag internationellt ledande. Han var en typisk exponent för "det röda Umeå", en salig 
ARKIV | NR 8 | RECENSION

blandning av gammal och ny radikalism; icke desto mindre valde han i kärnkraftsomröstningen 198I att stödja linje 2, "avveckling med förnuft", medan de flesta på den kanten sympatiserade med linje 3.

Utgivarna hoppas att Sörens Wibes eftermäle ska inspirera till efterföljd. Det är kanske en förhoppning av det frommare slaget. Yrkespolitikern, tidigt utblommad, har eliminerat sakpolitikern, den som aldrig ger upp sin vision och sitt engagemang. 


\section{Moderna klassiker}

\section{Arkiv förlag}

Hur ska vi gemensamt kunna använda och samtidigt vårda världens resurser på ett för framtiden hållbart sätt? I sin epokgörande bok Allmänningen som samhällsinstitution (Governing the Commons) utmanar Elinor Ostrom, som fick Nobelpriset i ekonomi 2009, de uppfattningar som bara ser två lösningar på "allmänningens tragedi": privatisering eller statlig reglering. Hon visar att människor genom frivillig organisering kan skapa livskraftiga institutioner som förmår att förvalta ömtåliga och knappa resurser. Ostroms teori har räckvidd och relevans långt utöver de sammanhang hon studerar.

Arkiv förlag, 368 sidor 


\section{Jonny Hjelm \\ Skogsarbetarna och motorsågen}

En studie av arbetsliv och teknisk förändring

Skogsbruket har genomgått en snabb och omvälvande mekanisering under efterkrigstiden. Syftet med denna bok är att studera hur skogsarbetarna upplevt och agerat i denna förändringsprocess. Huvudintresset ägnas mekaniseringens första fas, då motorsågen slog ut timmersvansen och yxan. Samtidigt får vi en inblick i hur livet på landsbygden förbättrades under 1940- och 1950-talen och hur denna utveckling banade väg för en stark framtidsoptimism.

Arkiv förlag 1991, mjukband, 257 sidor

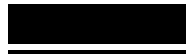

\section{Bo Persson}

\section{Skogens skördemän}

Skogs- och flottningsarbetareförbundets kamp

för arbete och kollektivavtal 1918-1927

Denna bok handlar om Skogs- och flottningsarbetareförbundets första tio år. Förbundet kämpade för att etablera kollektivavtal, och hade till en början vissa framgångar, men de vidare framgångarna uteblev. Bakom misslyckandet låg främst det förhärskande kontraktssystemet, de sociala skillnaderna mellan arbetarna, överflödet på arbetskraft och de mäktiga skogsbolagens motstånd.

Arkiv förlag 1991, mjukband, 228 sidor

»Läs mer om böckerna på www.arkiv.nu« 